\title{
REVIEWING THE DISCOURSE ON (POTENTIAL) "ENEMIES OF STANDARD ENGLISH"
}

\author{
Yazid Basthomi \\ Universitas Negeri Malang, Malang
}

\begin{abstract}
This essay argues that Standard English is one among the varieties of English. Although speaking Standard English, as is the case with speaking other languages or varieties claimed to be the standard, might allow the speakers to gain particular privileges, it should not be readily surmised that this variety is more quality than the rest; difference does not necessarily mean difference in quality. As such, Honey's propagation that Standard English is more qualitythus warrants more attention - should be read on guard. This essay outlines whom Honey refers to as the enemies of Standard English. Subsequent to the outline, the essay presents points disclosing Honey's shaky argument. Critical presentation, against the backdrop of Honey's argumentation, of issues about nonnative speakers of English (if they are parties having the potential to corrupt English) will conclude the article.
\end{abstract}

Key words: Standard English, variation, English as a foreign language

As English has been (propagated as) a global language, the number of its speakers has, consequently, been getting increasingly bigger. However, what needs remembering is that native speakers of English are less in number than those speaking the language as a second/foreign language (Graddol, 1997; Crystal, 1997). Even so, nonnative speakers of English are likely to be in a disadvantaged position in the world discourse, for the world discourse is seemingly bound to be English discourse (Basthomi, 2005, Maurannen, 2003; Kaplan, 2000; Swales, 1990, 2004), meaning that nonnative speakers of English are in general unlikely to have a predominant control over the use of the language.

Let me recount one of my anecdotal memories. In a workshop relating to the English writing performance of international students at the English Language Institute, University of Michigan-Ann Arbor, in early 2006, Professor John Swales of the Institute, jokingly pointed out that the use of the word "researches" as the plural form of "research" in academic written texts has been a form of linguistic 
"destruction" brought about by nonnative speakers of English like me. Such a statement, albeit jocular in nature, instantaneously brought Honey's Some Enemies of Standard English to my attention; I felt immediately "vulnerably subject" to being "sued" as the enemies of Standard English due to my potential failure, as a learner of English as a foreign language, to fully acquire the language. Feeling (academically) insecure, I felt the need to critically reread Honey's argumentation undergirding his Some Enemies of Standard English. This paper is literally the presentation of the result of that reading.

Honey is palpably a belligerent advocate of Standard English. He asserts that Standard English is a variety of more quality than other varieties of English, which, therefore, necessitates people to use it. He accuses some linguists, such as, Chomsky, Labov, and Pinker, of being the enemies of Standard English, for he thinks they have generated concepts which belittle the status of Standard English as the most quality among English varieties. In what follows, we will examine how Honey criticises those linguists he deems the enemies of Standard English and scrutinize Honey's presumptions around this issue.

\section{HONEY'S DEFINITION OF ENEMIES OF STANDARD ENGLISH}

Chomsky's idea of human's linguistic complex fixed mental machinery is Honey's first target. This concept is said to underpin the idea that every human being has psychological potential for acquiring language, which entails the notion that all languages, dialects and variations, for they are conceived of as due to that common mental potential, then, have equal quality; no language, dialect, and variation is superior to the others. It is this notion which makes Honey restless. $\mathrm{He}$, on page 44-45, simplifies Chomsky's proposition using his words as follows:

An important corollary of Chomsky's theory of essentially innate linguistic capacity is the assumption that all human languages are cut to a common pattern, since they are all, of course, determined by that psychological structuring which is innate to our species.

By relegating to this point, Honey seems to have a justifying base for leaping to a conclusion that all human languages and dialects are equally good to which he disagrees. However, it is noticeable that Honey glosses over an important venue where Chomsky proposes points of possible difference among language usersnot necessarily that they do the same in pattern in every aspect of linguistic per- 
formance. Chomsky's concept of performance signifies that an individual might produce linguistic performance different from his or her fellow friends do, whilst the notion of parameters (Cook, 1996; Cook \& Newson, 1996), Chomsky advocates, bear another idea that languages, dialects, and variations may have their own characteristics which make them different from each other. Yet, one cannot jump to a point that being different from each other as such, language, dialect and variation necessarily mean different in quality as Honey is eager to conclude.

Likewise, Labov cannot get rid of Honey's attack, for Labov, who is keen on vast variations of languages and dialects, is also deemed to be the proponent of the idea that all languages, dialects, and variations are the same in quality. At this point, Honey says, Chomsky and Labov, who somehow have different basic theoretical tenets, share something in common in that both generate the same conception that all languages, dialects, and variations are equally good. This point is what makes Honey upset.

Elsewhere in the chapter, Honey is vigilant to pinpoint Pinker's stance which fails.

[1] to explain how the underlying capacity, the innate 'instinct' for language, translates into actual ability to use the grammar, phonology, and vocabulary of one specific language; and [2] to explain the relationship of that innate ability to the acquisition of the working rules which guide us in handling language in socially sensitive ways (p. 47).

Honey also works well to demonstrate that language is a 'cultural artefact', a point which is negated by Pinker. At this point, it seems that Honey is not as yet going to stop attacking Pinker from several angles, which shows that Honey is blithe enough to dismantle Pinker's weak argumentation. Honey is successful to disclose Pinker's self-contradictory stance (p. 49); on the one hand, Pinker claims that every speaker uses grammar of his or her dialect correctly, whilst, on the other hand, Pinker confesses that he is 'enraged' by the word disinterested which he considered incorrect (p. 50). Honey can still further pinpoint Pinker's drawback in that he is ignorant of the fact that 'anthropological evidence suggests that for all languages, even in the most "primitive" societies, there exist standards of usage and that in such societies, certain individuals are considered to be better models of speech than others' (p. 50).

Far from being content with his critical remarks on Chomsky, Labov, and Pinker, Honey continues criticising some other figures such as Cameron, Leith, 
Crowley, Brakel, Joseph and some others who focus their proposition on the idea that Standard English is class and power elite dialect, which means that the plea such as that of Honey refers to the articulation of hegemonic domination by those in control in the society. Therefore, Honey, with an equal force, accuses them of being politically laden - left-ideology driven.

\section{UNRA VELING HONEY'S WACKY STANCE}

Thus far, it has been clear who Honey means by the enemies of Standard English and what make Honey deem them the enemies of Standard English. Further, we turn to Honey's presumptions about issues around the idea of Standard English. Throughout the chapter, Honey presumes that: 1) language is a cultural artefact (p. 47), 2) for all languages, even in the most primitive societies, there exist standards of usage and that in such societies, certain individuals are considered to be better models of speech than others (p. 50), 3) Standard English confers privilege (p. 53), 4) written Standard English is something crucially different from everyday English (p. 51), 5) Standard English is a specialised variety (p. 48) which requires one to have prolonged exposure, formal instruction, and careful attention to rules (p. 49) in order to master it.

In regard to the first point, language as a cultural artefact, it is legitimate to say that language, dialect, and variation have cultural value system (Dobson, 2001; Lehtonen, 2000) which might be exclusive as well as inclusive; one culture might and might not share things in common with others. Simply when an Indonesian listens to Malaysian language spoken, to give a sheer example, he or she might have negative judgement to the language due to his or her horizons of expectation which are not gratified (Cook, 1994; Freund, 1987; Horton, 1979; Jauss, 1992). Yet, a question arises as to who can guarantee that a similar negative judgement does not happen to a Malaysian who also happens to hear Indonesian spoken language in use. This merely bears a notion that being different does not automatically and necessarily mean different quality. Nevertheless, this is obviously Honey's stance; he easily flees to immature conclusion that difference must connote difference in quality. Thus, if it is so, he is justified to say that Blair's speech is more quality than Bush's or the other way round as he wishes.

Honey's assumption that standard usage always exists in every society, even in the most primitive one, strangely does not work in herding him to believe that there is equality among the standards. Even, elsewhere, he is content with his knowledge that Singaporeans praise his Singaporean friend who happens to have 
British accent, for by means of which, he is believed to possess more intellectuality-educatedness - than they do (Honey, 1991). This example embraces and, therefore, confirms his third point that Standard English confers privilege. Pragmatically, it could be so, but it is not the point. He clearly confuses things. He is ignorant of the fact that the predication and praise of 'British-like accent' entitled to the Singaporean as well as the conferred privileges one might gain are extrinsic attributes people generate. They are not the intrinsic properties of Standard English he painstakingly advocates nor of the other standard as well as non-standard languages. In regard to this, Milroy (1999:16) has an excellent idea as the following:

[...] languages are not themselves moral objects. One language may use verbs at the end of clauses and another in the middle, but it cannot be shown that one word-order is in some way superior - more virtuous, more expressive - than the other. Much the same can be said of phonological and lexical structures. Thus (and this is the position of most professional linguistic scholars), no moral judgement or critical evaluation can be validly made about the abstract structures we call languages. It is the speakers of languages, and not the languages themselves, who live in a moral universe.

Another case might well exemplify a similar situation that when an applicant is rejected for a job due to his dialect and/or accent which an interviewer happens to dislike, it is not the intrinsic value of his speech which is 'bad', rather, the extrinsic-ideological schema (Jeffries, 2001; An-Nabhani, 1953) which the interviewer has, which likely leads him to judge the applicant's inferiority. This case, in Milroy's (1999: 19) words is a form of discrimination, as the following excerpt insinuates.

There are now many examples of language discrimination in the literature. V. Edwards (1993: 235) quotes a letter from an interview panel to an unsuccessful candidate for a teaching appointment openly stating that despite excellent qualifications he has been rejected because of minor aspects of his spoken English (essentially a London accent) [...]. In a prescient essay first written in 1951, Abercrombie (1965) was able to comment that in Britain at that time, the 'accent-bar' was as strong as what was then referred to as the 'colour-bar'. There was no exaggeration in this: the accent-bar was overtly and widely used to exclude people with localised accent from professional advantage, [...]. 
Combining Honey's presumptions, especially no. 2 and 4, we will be able to grasp that he is, to some degree, trying to say that Standard English covers both spoken and written. When he touches upon the fact that some tribal chiefs are orators - good models, it is apparent that he is trying to assert that those are the examples of standard spoken language. As well, when he says that 'standard written language is something crucially different from everyday English' (p. 51), he is proposing that there is a "standardness" in written form of languages, including English. Nonetheless, this does not leave us absent of question as to what and/or which he means by Standard English, whereas, undeniably, English is used by a great deal of people in different regional boundaries or societies which, in accordance with his own words, must possess 'chiefs' as good speech models. In other words, the question is, among the 'chiefs' who use English, who he will choose as the models whilst they are (if he is free from his subjectivity) the same, representing good models of standards (plural is emphasised here) spoken language. Among Blair, Bush, and Howard, we are wondering whose English he will likely choose as a good model of Standard English, whereas he, hitherto, has advocated one Standard English.

Concerning Honey's explanation about standard written English, Crowley (1999: 271) has captured Honey's complacent statement as follows.

On page 1 of Language is Power Honey defines the problematic term: 'By standard English I mean the language used in which this book is written, which is evidently the same form of English used in books and newspapers all over the world.

Obviously, on one occasion, Honey excludes some English speakers of certain variety, especially, when he deals with spoken English, but, on the other occasions, he tries to embrace wide coverage, the coverage of his 'standardly written book.' In the latter sense, there are considerable books written by those who Honey is likely to exclude as the models of standard spoken English. I have my doubt that Honey will consider Achebe as a model of standard spoken English if Achebe does not have the accent (regarding Achebe's cultural background, this is quite likely) Honey prefers, whilst, at the same time, Achebe's books written in English are also widely read like his, which posits the idea that the books meet Honey's 'definition' of standard written English.

Another point of Honey's obscurity in defining standard spoken and written English or Standard English as he calls it is his failure to address the virtue of the 
difference between spoken and written language. Spoken language obviously does not give someone the luxury of time as relatively enough as the written one in its use. Again, we are wondering how he would judge Blair's speech (in his words, Blair could be said to be a chief who is usually good an orator as a model of standard speech) if Blair happens to stutter, which is probable to happen, most of the time. We still might wonder how he would call a 5 year old child's speech which runs like that of an adult real great orator. Again, this signifies how problematic the concept of Standard English which Honey is frantically pleading without first defining clearly what he means by the term.

It is interesting to heed Milroy's comment on Honey, as the following, for our reflection although, apparently, Milroy's definition of Standard English is as vague as Honey's in this limited quotation.

For John Honey, for example, many linguistic researchers can be identified by name as 'the enemies of standard English'. The list of 'enemies' makes entertaining reading, as it contains some strange bedfellows, including, astonishingly, Noam Chomsky, whose theories of the 1960s and 1970s appeared to be based entirely, and very narrowly, on standard English. The fact that these 'enemies' may themselves have done a great deal of research on the history and use of standard English, is apparently, in this moral crusade, of no relevance at all (Milroy, 1999: 22).

Further, other Milroy's words are worth citing, which gives the idea of categories into which we might classify Honey.

When present-day language scholars write about standard languages and prescriptive rules, they often distinguish two types of people who display attitudes towards language use. On the one hand, there is the general public, many of whom have strong attitudes towards linguistic correctness, and who keep writing to the newspapers denouncing trivial mistakes in usage. On the other hand, there is a group of people who are said to have more enlightened attitudes based on scholarly research on the structural properties of language. These are, of course, present-day experts in linguistics and language studies, who are often sociolinguists. Some of these experts have felt that, as a matter of scientific responsibility, they had a duty to venture outside narrowly academic concerns in order to promote public tolerance of variation in language and to point out that it is wrong to discriminate against individuals on linguistic grounds, just as it is wrong to discriminate on grounds of race or colour of skin (Milroy, 1999: 19). 


\section{SOME POINTS OF AFTERTHOUGHT}

Despite the apparent Honey's failing argumentation, the position of nonnative speakers of English as, potentially, perpetrators of some corruption in the use of English warrants some attention. As noted earlier, Indonesian speakers/learners of English as a foreign language, to cite an example, are prone to failure in mastering the language. Subsequently, they will have idiosyncratic use of English such as the pluralization of "research" into "researches."

Towards such probable "corruption" (should it be called so), I would like to call upon the fact that personal-idiosyncratic variation in the use of language, including the target language, is bound to happen. Therefore, that some linguistic "corruption" takes place is a natural phenomenon, thus, indispensable. Another point to note is that an example of the pluralized form of "researches" or, in a more general term, "nativized English" as Flowerdew (2001) calls it, tends to be tolerated by native speakers of English (Flowerdew, 2001). In addition, we might look at some differences between American and British English which, in general, do not necessarily pose any significant problem in communication. A good anecdotal example in this line is that around a dinner table at a potluck party in February 2006, Professor John Swales brought some shrimp and, in response to a question about what he brought, he said, "Er ... some shrimps." Towards this, a fellow American asked, "John, did you say shrimps or shrimp?" So, briefly put, the plu$\mathrm{ral} /$ singular phenomenon is not necessarily a matter of "corruption" resting on the blemished performance of nonnative speakers of English. English "shrimps" might be shared by Americans who tend to use "shrimp" without the plural marker "s".

So, what is crucial is that, the potential destruction of English, and particularly, Standard English, should not impede nonnative speakers of English from using the language, including the writing of papers, articles, book chapters, books and the like in English. Should some inaccuracies surface, they should not readily be deemed a total failure; some might potentially be accepted by the public. Remember that some shops in Australia use words like supa valu which indicate that, orthographically, English is, to some extent, superfluous; therefore, the words "super value" need truncating. In addition, a TV program in an Australian TV station is devoted to spelling contest for students. This situation insinuates that English is orthographically not simple, even for its native speakers. In this regard, it can be safely concluded that the assumption underlying the spelling contest is that the contest is an effort to guarantee that the coming generations of Australian native speakers of English inherit sound knowledge of the spelling of English, which is 
not necessarily easy; if it is hard for native speakers, it is very likely to be harder for nonnative speakers of the language. In this line of argument, inaccuracies of nonnative speakers of English in using the language should not be considered as corrupting or destroying the language.

\section{REFERENCES}

An-Nabhani, T. 1953. Nidzom el Islam. El Quds: Daar el Ummah.

Basthomi, Y. 2005. Linguistic Debilitation of Indonesian Academics. A paper presented at the $2^{\text {nd }}$ Workshop Series on Local Scholarship and the Study of Southeast Asia: Bridging the Past and the Present, convened by the Southeast Asian Studies Program, Faculty of Arts and Social Sciences, National University of Singapore, 8-12 July 2005.

Cook, G. 1994. Discourse and Literature: The Interplay of Form and Mind. Oxford: Oxford University Press.

Cook, V. 1996. Second Language Learning and Language Teaching ( $2^{\text {nd }}$ edn). London: Arnold.

Cook, V. and Newson, M. 1996. Chomsky's Universal Grammar. Oxford: Blackwell.

Crowley, T. 1999. 'Curiouser and Criouser: Falling Standards in the Standard English Debate', in T. Bex \& R.J. Watts (Eds.), Standard English: The Widening Debate (pp. 271-282). London: Routledge.

Crystal, D. 1997. English as a Global Language. Cambridge: Cambridge University Press.

Dobson, A. 2001. Teaching of Culture within Foreign Language Teaching and Its Relationship to Nationalism. Australian Review of Applied Linguistics, 24 (1), 61-73.

Flowerdew, J. 2001. Attitudes of Journal Editors to Nonnative Speaker Contributions. TESOL QUARTERLY, 35 (1), 121-150.

Freund, E. 1987. The Return of the Reader: Reader Response Criticism. London: Methuen \& Co. Ltd.

Graddol, D. 1997. The Future of English? London: The British Council.

Honey, J. 1991. 'The Concept of 'Standard English' in First and Second Language Contexts', in M. L. Tickoo (Ed.), Language \& Standards: Issues, Attitudes, Case Studies (pp. 23-32). Singapore: SEMEO Regional Language Centre.

Honey, J. 1997. Language is Power: The Story of Standard English and Its Enemies. London: Faber and Faber. 
168 TEFLIN Journal, Volume 18, Number 2, August 2007

Horton, S. R. 1979. Interpreting Interpreting. Baltimore: The Johns Hopkins University Press.

Jauss, H. R. 1992. ' Literary History as a Challenge to Literary Theory', P. Rice \& P. Waugh (Eds.), Modern Literary Theory ( $2^{\text {nd }}$ rev. edn) (pp. 83-90). London: Edward Arnold.

Jeffries, L. 2001. 'Schema Affirmation and White Asparagus: Cultural Multilingualism among Readers of Texts'. Language and Literature, 10 (4), 325-343.

Kaplan. R. 2000. Why is English a Global Language? Problems and Perplexities. In H. W. Kam and C. Ward (Eds.), Language in the Global Context: Implications for the Language Classroom (pp. 268-283). Singapore: SEAMEO Regional Language Centre.

Lehtonen, M. 2000. The Cultural Analysis of Texts. London: SAGE Publications.

Mauranen, A. 2003. The Corpus of English as Lingua Franca in Academic Settings. TESOL Quarterly, 37(3), 513-527.

Milroy, J. 1999. 'The Consequences of Standardisation in Descriptive Linguistics', in T. Bex \& R. J. Watts (Eds.), Standard English: The Widening Debate (pp. 16-39). London: Routledge.

Swales, J. M. 1990. Genre Analysis: English in Academic and Research Settings. Cambridge: Cambridge University Press.

Swales, J. M. 2004. Research Genres: Explorations and Applications. Cambridge: Cambridge University Press. 